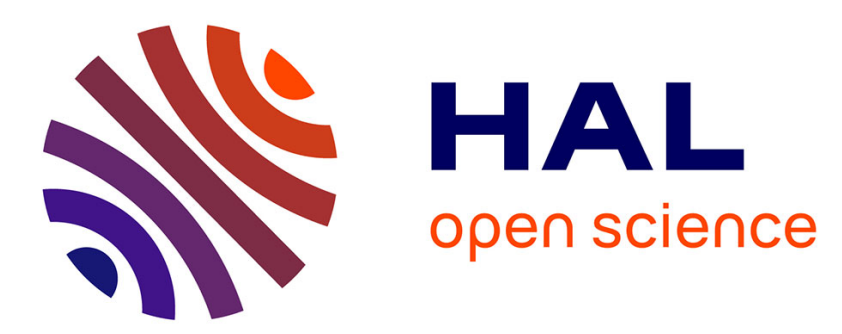

\title{
Search for new manganese-cobalt oxides as positive electrode materials for lithium batteries
}

Pierre Strobel, Jérémy Tillier, Audrey Diaz, Alejandro Ibarra-Palos, François

\author{
Thiéry, Jean-Bruno Soupart
}

\section{- To cite this version:}

Pierre Strobel, Jérémy Tillier, Audrey Diaz, Alejandro Ibarra-Palos, François Thiéry, et al.. Search for new manganese-cobalt oxides as positive electrode materials for lithium batteries. Journal of Power Sources, 2007, 174 (2), pp.910-915. 10.1016/j.jpowsour.2007.06.080 . hal-00186061

\section{HAL Id: hal-00186061 https://hal.science/hal-00186061}

Submitted on 9 Nov 2007

HAL is a multi-disciplinary open access archive for the deposit and dissemination of scientific research documents, whether they are published or not. The documents may come from teaching and research institutions in France or abroad, or from public or private research centers.
L'archive ouverte pluridisciplinaire HAL, est destinée au dépôt et à la diffusion de documents scientifiques de niveau recherche, publiés ou non, émanant des établissements d'enseignement et de recherche français ou étrangers, des laboratoires publics ou privés. 


\title{
Search for new manganese-cobalt oxides as positive electrode materials for lithium batteries
}

P. Strobel, J. Tillier, A. Diaz, A. Ibarra-Palos, F. Thiéry and J.B. Soupart*

Laboratoire de Cristallographie CNRS, BP 166, 38042 Grenoble Cedex 9, France

*Erachem-Comilog, B-7343 Tertre, Belgium

\begin{abstract}
Two new mixed manganese-cobalt oxides for lithium battery positive electrode materials were obtained using original synthesis routes. Compound I, "LMCO" is a new form of $\mathrm{LiMnCoO}_{4}$ obtained by ion-exchange from $\mathrm{NaMnCoO}_{4}$. Compound II, "MCO" is a nanometric material with formula $\mathrm{Mn}_{1-\mathrm{x}} \mathrm{Co}_{\mathrm{x}} \mathrm{O}_{\approx 2}$ obtained by quenching in specific conditions. We showed recently that the electrochemical properties of this materials were dramatically enhanced by cobalt doping [Strobel et al., J. Mater. Chem. 15 (2005) 4799]. The effect of cobalt content on its electrochemical behaviour is reported in detail here. Compound I gives rise to two reversible single-phase intercalation reactions centered at 2.7 and $4.4 \mathrm{~V}$ on discharge, corresponding to $\mathrm{Co}^{3+} / \mathrm{Co}^{4+}$ and $\mathrm{Mn}^{3+} / \mathrm{Mn}^{4+}$ redox couples, respectively. The initial capacity is $160 \mathrm{mAh} / \mathrm{g}$ at low regime, but stabilizes at ca. $100 \mathrm{mAh} / \mathrm{g}$ on extended cycling. Compound II gives a single plateau with a much higher capacity. An optimum ratio of $\mathrm{Co}: \mathrm{Mn}=0.20$ was found and gives a capacity of $175 \mathrm{mAh} / \mathrm{g}$ after $60 \mathrm{cycles}$ in the potential window $2.0-4.2 \mathrm{~V}$.
\end{abstract}

\section{Introduction}

$\mathrm{LiCoO}_{2}$ with $\mathrm{NaFeO}_{2}$-type structure is the best positive electrode material for rechargeable lithium batteries so far. Many efforts are underway to replace part or all cobalt by cheaper and environmentally friendlier elements. Manganese is one of the most attractive alternates, and numerous manganese compounds (spinel, layered, amorphous oxides) have been considered as positive electrode materials $[1,2]$. Interestingly, cobalt, as a dopant, has a very positive effect on the electrochemical performances of manganese oxides. This has been established in the Li-Mn-O phases with spinel [3-7], birnessite $[8,9]$, orthorhombic [10] and monoclinic $\mathrm{LiMnO}_{2}$ [11].

This paper reports results of search for new Mn-Co oxides for lithium intercalation in two different systems. The first example concerns a new phase derived from $\mathrm{NaCo}_{2} \mathrm{O}_{4}$. This sodium cobaltate was first described by Jansen and Hoppe in a layered structure, space group $\mathrm{P} 63 / \mathrm{mmc}, \mathrm{a}=0.2843 \mathrm{~nm}, \mathrm{c}=$ $1.0811 \mathrm{~nm}$ [12]. Li et al. [13] recently showed that up to $50 \%$ Co can be replaced by $\mathrm{Mn}$, yielding $\mathrm{NaCoMnO}_{4}$ with a similar structure and a slightly expanded unit cell $(\mathrm{c}=1.128 \mathrm{~nm})$. We repeated the preparation of $\mathrm{NaCoMnO}_{4}$ and used this phase as a precursor to obtain a lithium derivative, $\mathrm{LiCoMnO}_{4}$, by ion exchange. Its electrochemical behaviour as positive electrode vs. lithium will be reported here.

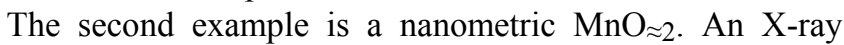
amorphous manganese oxide was reported to form by quenching in a narrow temperature range around $370^{\circ} \mathrm{C}$ by Feltz et al. [14]. We recently showed that this material is in fact nanocrystalline, and that it is an interesting positive electrode material for lithium batteries ; last but not least, copper or cobalt substitution was found to induce a large improvement in capacity retention, with cobalt superior to copper as a dopant [15]. The initial dopant concentration was rather arbitrarily chosen at $\mathrm{M}: \mathrm{Mn}=0.20$. We present here a study of the electrochemical behaviour of material for variable cobalt doping levels varying between 0 and 0.30 (as molar $\mathrm{Co} / \mathrm{Mn}$ ).

\section{Experimental}

The synthesis of $\mathrm{LiCoMnO}_{4}$, hereafter abbreviated LCMO, includes two steps. $\mathrm{NaCoMnO}_{4}$ was first prepared by solidstate reaction of appropriate proportions of sodium carbonate, $\mathrm{Co}_{3} \mathrm{O}_{4}$ and $\beta-\mathrm{MnO}_{2}$ powders. The mixture was ground in an automatic grinder/mixer for 30 minutes under ethanol, then transferred to an aluminum boat and fired at $1000^{\circ} \mathrm{C}$ for 18 hours under oxygen flow [13]. This sequence was repeated twice to yield phase-pure $\mathrm{NaCoMnO}_{4}$. In a second step, the latter was treated in $\mathrm{LiCl}-\mathrm{LiNO}_{3}$ eutectic at $280^{\circ} \mathrm{C}$ for 6 hours, then rinsed in hot distilled water.

The preparation of $\mathrm{Mn}_{1-\mathrm{x}} \mathrm{Co}_{\mathrm{x}} \mathrm{O} \approx 2$ was described previously [15]. In short, it consists in firing a freshly coprecipitated MnCo carbonate in air at $370 \pm 5{ }^{\circ} \mathrm{C}$, followed by quenching between metallic plates in air. The product is an oxide consisting of homogeneous microspheres with diameter ca. 1 $\mu \mathrm{m}$ [14]. Four samples were prepared with $\mathrm{Co} / \mathrm{Mn}$ molar ratios $0.05,0.10,0.20$ and 0.30 ; they will be we abbreviated hereafter MCO-05, MCO-10, MCO-20 and MCO-30, respectively.

All products were characterized by X-ray diffraction (XRD) using a Siemens D5000 diffractometer with $\mathrm{Cu} \mathrm{K \alpha}$ or $\mathrm{Fe} \mathrm{K} \alpha$ radiation, mounted in transmission geometry. Cell parameters were determined by a least squares method.

The morphology of samples was investigated using a Jeol 840 scanning electron microscope. Cationic ratios were determined by EDX analysis coupled with the SEM.

Positive electrode paste was prepared from intimate mixtures of the oxides with carbon black and PTFE emulsion in weight ratio ca. 70:20:10. The paste was laminated to 0.1 $\mathrm{mm}$ thickness, cut into pellets with diameter $10 \mathrm{~mm}$ and dried at $240^{\circ} \mathrm{C}$ under vacuum. These conditions were found adequate to dry completely the pellets. Typical active material masses used were in the range 5-15 mg. Electrochemical tests were carried out in liquid electrolyte at room temperature using Swagelok-type batteries at room temperature. The electrolyte was a $1 \mathrm{M}$ solution of $\mathrm{LiPF}_{6}$ in EC-DMC 1:2 (Merck Co.). Negative electrodes were $200 \mu \mathrm{m}$-thick lithium foil (Metall Ges., Germany). Cells were assembled in a glove box under argon with $\leq 1 \mathrm{ppm} \mathrm{H}_{2} \mathrm{O}$. Electrochemical studies were carried out using a MacPile Controller (Bio-Logic, Claix, France) in either galvanostatic mode or by step-potential electrochemical spectroscopy (SPES), using typically $10 \mathrm{mV} / 30 \mathrm{mn}$ steps.

\section{Results and discussion}

\subsection{Structural characterization}

- LCMO : An XRD pattern of freshly prepared LCMO is shown in Figure 1. It is not single-phase. The data can be ascribed to a majority $\mathrm{LiMO}_{2}$-type layered phase and a minority spinel one. Refined cell parameters are: $\mathrm{a}=0.2829(1)$ $\mathrm{nm}, \mathrm{c}=1.469(2) \mathrm{nm}$ for the layered phase (most probable space group R-3m), $a=0.8229(6) \mathrm{nm}$ for the spinel phase. The weight fraction of the minority phase is ca. $12 \%$. These results show that the hexagonal lithium phase formed has a different layer stacking from that in the sodium parent phase $(\mathrm{c}=1.128$ 
$\mathrm{nm})$. In spite of the proximity of the second phase cell parameter with that of $\mathrm{LiMn}_{2} \mathrm{O}_{4}(\mathrm{a}=0.824 \mathrm{~nm})$, the impurity is probably an intermediate phase between $\mathrm{CoMn}_{2} \mathrm{O}_{4}(\mathrm{a}=0.839$ $\mathrm{nm})$ and $\mathrm{Co}_{3} \mathrm{O}_{4}(\mathrm{a}=0.808 \mathrm{~nm})$ This can be inferred from the high intensity of the 220 reflection (at $2 \theta=38.5^{\circ}$ in Figure 1); since this reflection is essentially due to the contribution of the spinel A-site cations, it would have negligible intensity if this site was occupied by light lithium atoms.

The hexagonal phase obtained using this route differs significantly from a previously reported $\mathrm{Li}_{\mathrm{x}}\left(\mathrm{Co}_{1 / 2} \mathrm{Mn}_{1 / 2}\right) \mathrm{O}_{2}$, which has $\mathrm{c}=1.445 \mathrm{~nm}$ [16]. It is also a different phase from the spinel-type with similar stoichiometry $\mathrm{LiCoMnO}_{4}$, which has been obtained by direct thermal synthesis and exhibits a cubic cell parameter a $=0.8052 \mathrm{~nm}$ [17]. The use of a lowtemperature, topotactic synthesis route thus allowed to prepare a particular form of $\mathrm{Li}_{\mathrm{x}}\left(\mathrm{Co}_{1 / 2} \mathrm{Mn}_{1 / 2}\right) \mathrm{O}_{2}$, which is probably metastable. First-principles calculations indeed showed that phase separation between $\mathrm{LiMnO}_{2}$ and $\mathrm{LiCoO}_{2}$ is expected at equilibrium [18]

A close look at Figure 1 shows widely variable diffraction line widths for the hexagonal phase : compare for instance reflections 108 and 110 (in the $82-86^{\circ}$ range for $\mathrm{Fe} \mathrm{K \alpha}$ radiation). A detailed investigation of the structure of LCMO, including Rietveld refinement, will be published elsewhere [19].

Finally, it should be noted that this compound readily picks up water when stored in air atmosphere, and this induces remarkable changes in its XRD pattern. Thermogravimetric analysis and variable-temperature XRD measurements show that this phase transition occurs on heating at ca. $200^{\circ} \mathrm{C}$, and that it is reversible. More details about these features will be described elsewhere [19].

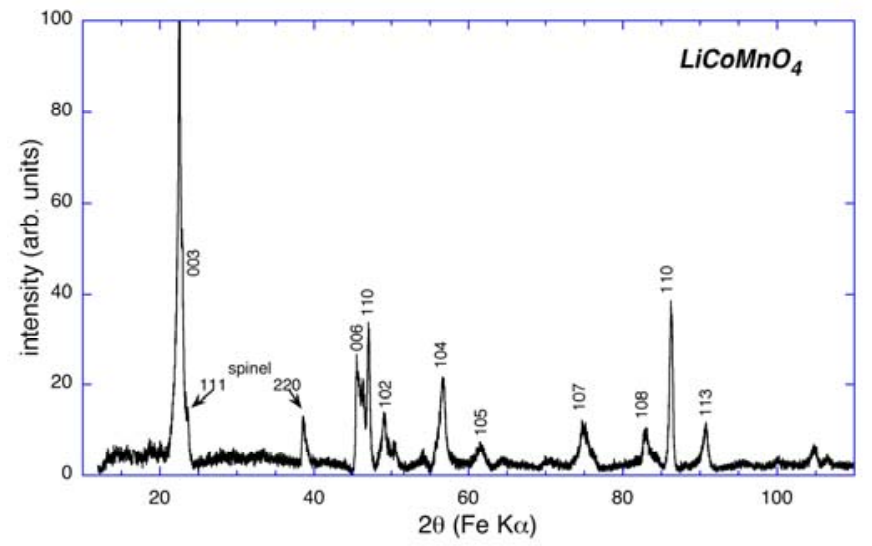

Fig. 1. XRD pattern of LCMO. The indexation of the main reflections is indicated.

- MCO: Figure 2 shows that all quenched MCO samples give only a few very broad diffraction peaks, whereas an unquenched sample shows distinct reflections corresponding to a mixture of $\mathrm{Mn}_{2} \mathrm{O}_{3}$ and spinel. Electron diffraction shows that quenched MCO samples are not amorphous, but nanocrystalline [14]. A typical SAED diagram of MCO-20 is shown in Figure 3. The cobalt content is found to have a negligible on the structural and microstructural properties of MCO.

\subsection{Physico-chemical characterization}

SEM observation shows a very different morphology for LCMO and MCO samples (see Figure 4). The former form plate-like grains as expected for a layered material, with a wide distribution in size. On the contrary, the latter form very uniform hollow spherical aggregates with sphere diameter close to $1 \mu \mathrm{m}$. This particular morphology is somewhat unexpected ; it is mostly encountered in synthesis routes including the decomposition of liquid droplets, such as spray pyrolysis [20]

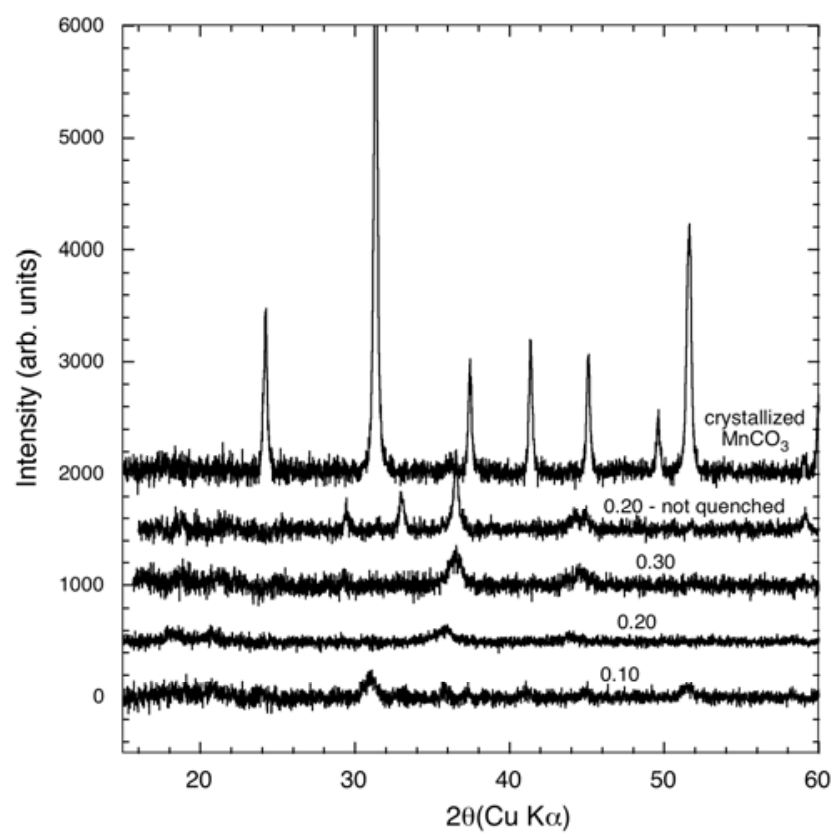

Fig .2. XRD pattern of MCO samples with various cobalt contents (Co:Mn molar ratios indicated). The pattern of standard $\mathrm{MnCO}_{3}$ recorded in the same conditions, is included for comparison (top).

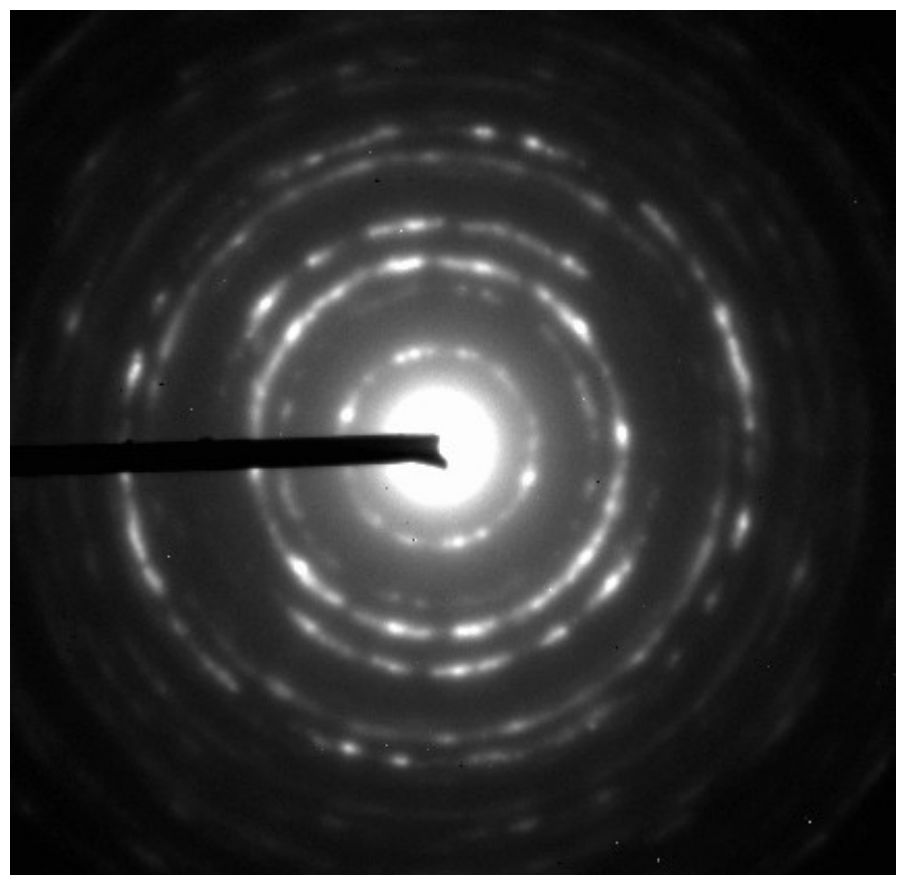

Fig. 3. Selected area electron diffraction pattern of a crystallite from sample MCO-20.

EDX analysis on numerous grains gave following results : in LCMO, the residual sodium was below detection level; in $\mathrm{MCO}$, the $\mathrm{Co} / \mathrm{Mn}$ ratios was consistent with the nominal one within experimental errors. The manganese oxidation state was checked for several MCO samples and found to be equal to $3.60 \pm 0.05$, whatever the cobalt content. 

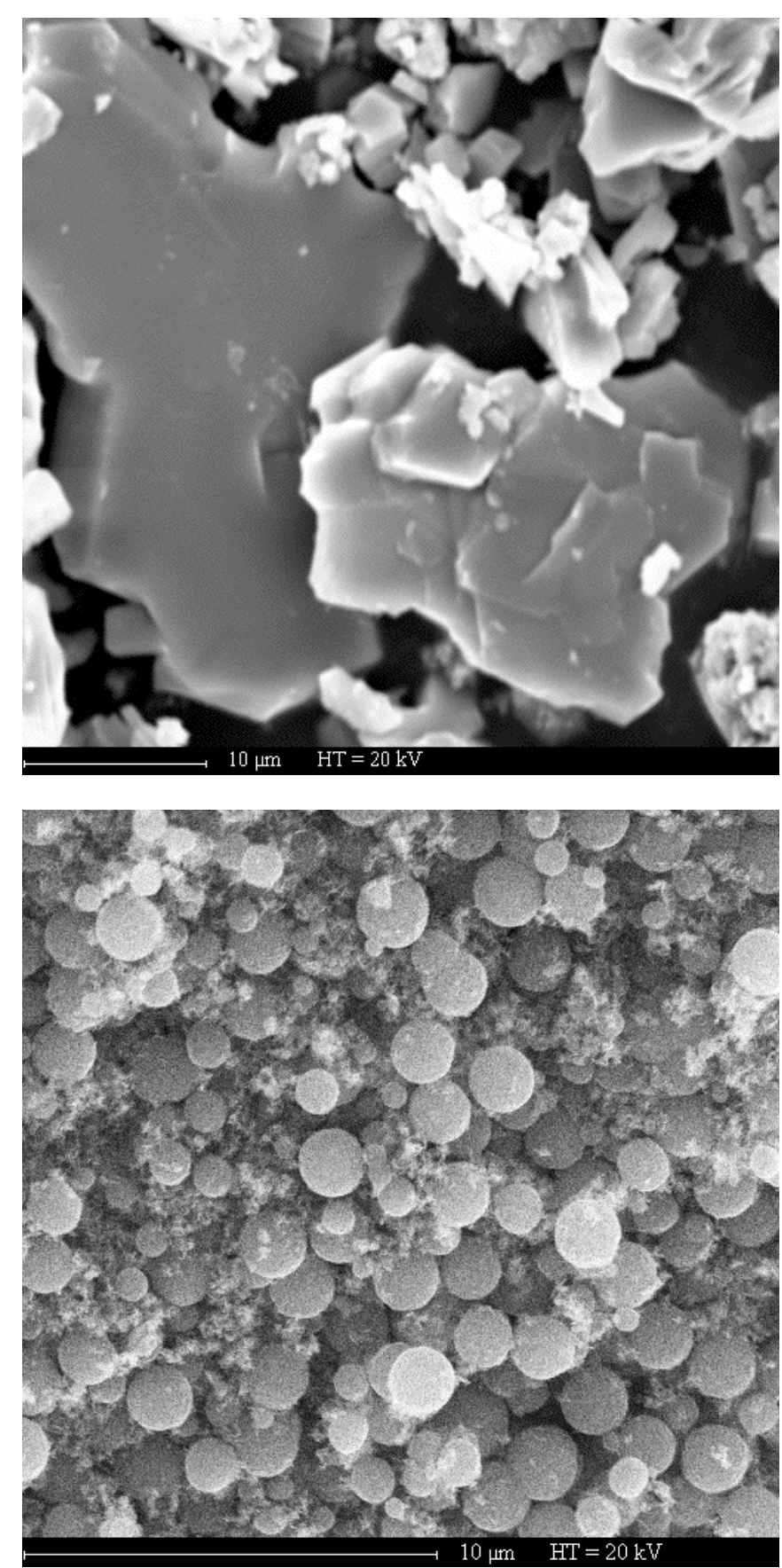

Fig. 4. SEM micrographs of typical grains of LCMO (top, 40 $\mu \mathrm{m}$ full scale) and MCO (bottom, $18 \mu \mathrm{m}$ full scale).

\subsection{Electrochemical behaviour - LCMO}

Slow-scanning step-potential measurements in the voltage window 2.0-4.8 $\mathrm{V}$ show that LCMO undergoes two separate, reversible, reactions centered at ca. 4.4 and $2.7 \mathrm{~V}$ on reduction (see Figure 5). The evolution of the current during potential steps in the peaks (not shown), as well as the overlap in potential between the reduction and oxidation peaks indicate that both reactions are single-phase. In view of previous data on neighbouring $\mathrm{Mn}$ and Co systems [16, 17, 20], the upper and lower potential peaks are ascribed to $\mathrm{Co}^{3+} / \mathrm{Co}^{4+}$ and $\mathrm{Mn}^{3+} / \mathrm{Mn}^{4+}$ redox reactions, respectively. Oddly enough, the upper reaction potential seems to shift to lower potentials with increasing cycle number (see the enlargement of the reduction curve in the 3.6-4.6 V region in Figure 5, bottom). No double current peak at $4 \mathrm{~V}$ typical of a transformation into spinel [21] was detected, even after 15 cycles.
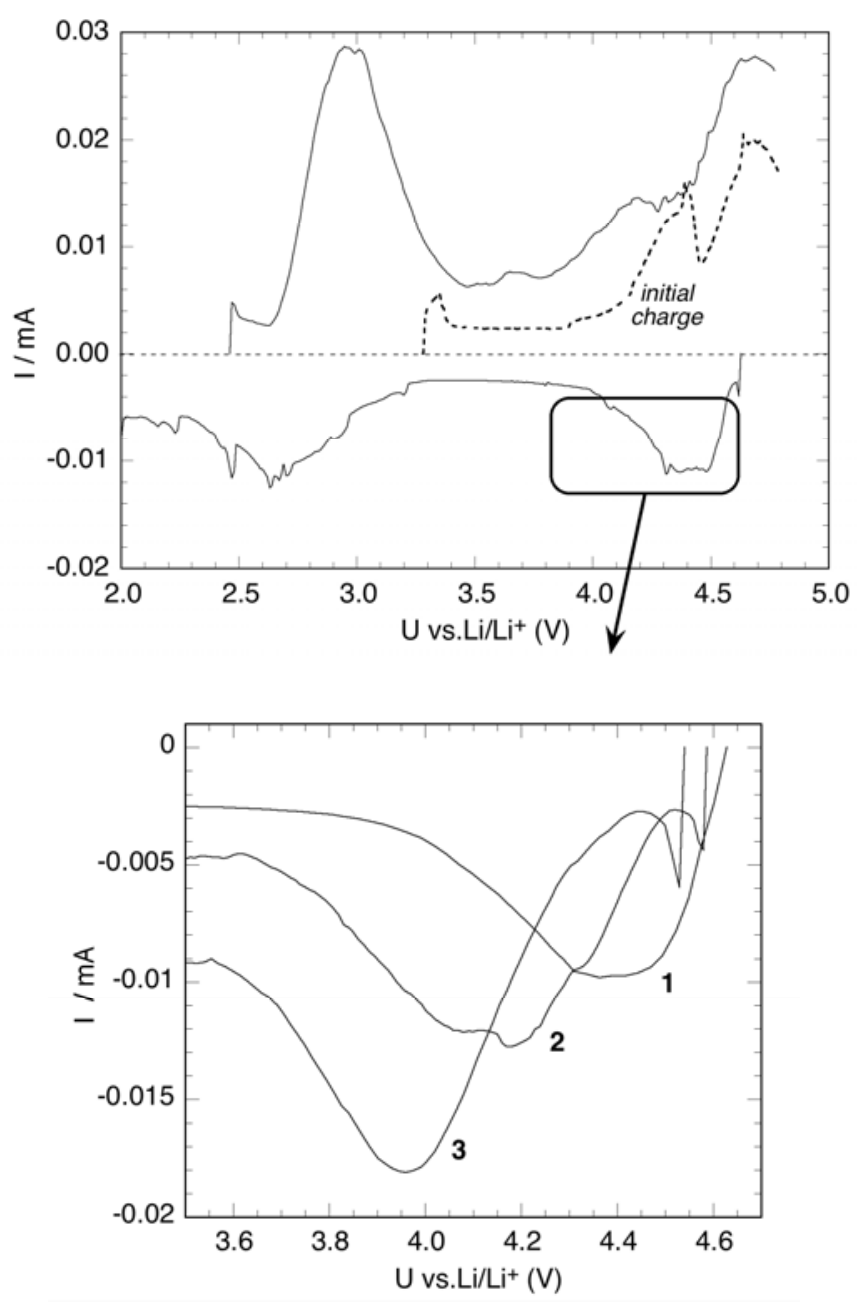

Fig. 5. Top: slow-scanning voltammogram $(10 \mathrm{mV} / 30 \mathrm{mn})$ of $\mathrm{LiCoMnO}_{4}$ in the potential range $2.0-4.8 \mathrm{~V}$ vs. $\mathrm{Li} / \mathrm{Li}^{+}$; bottom: enlargement of the first reduction peak region for cycles 1 to 3 (cycle numbers indicated).

The corresponding S-shape plateaus on the chargedischarge curve are shown in Figure 6. The initial total specific capacity $\mathrm{Q}_{\mathrm{s}}$ is about $160 \mathrm{mAh} / \mathrm{g}$. The capacity fraction above $4 \mathrm{~V}$ is low (ca. $60 \mathrm{mAh} / \mathrm{g}$ ), and could probably be extended by charging at higher voltages; however this voltage range leads to instabilities in the cells used.

The evolution of capacities on extended cycling is shown in Figure 7. The lower potential capacity is stable or even increases on cycling, while the upper potential one decreases. However, one cannot rule out parasitic oxidation problems at high voltage, and the present results for the upper voltage plateau may not reflect the intrinsic properties of the material. Previous reports on $\mathrm{Li}-\mathrm{Mn}-\mathrm{Co}-\mathrm{O}$ layered materials showed capacities above $4 \mathrm{~V}$ starting at ca. $90 \mathrm{mAh} / \mathrm{g}$ and constantly decreasing [16], or higher capacities with a tendency to transformation to spinel for lower cobalt contents [21].

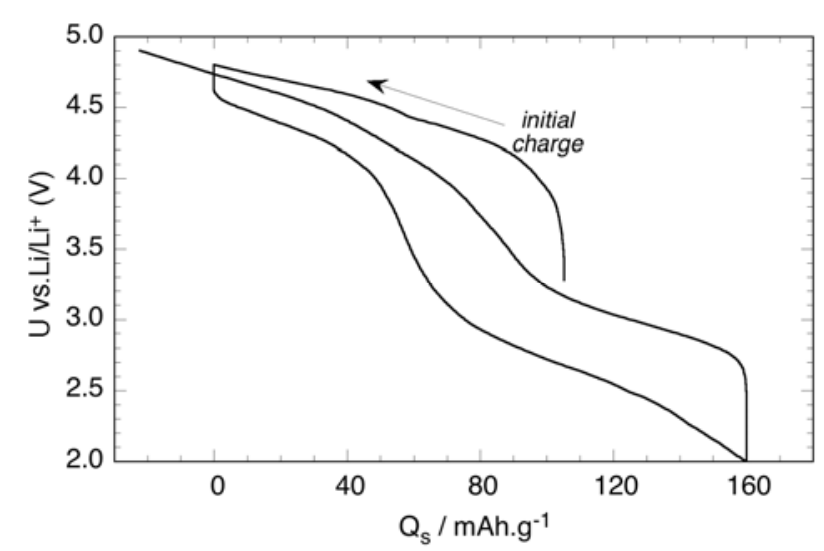

Fig. 6. First charge-discharge cycle of LCMO at $\mathrm{C} / 10$ regime. 


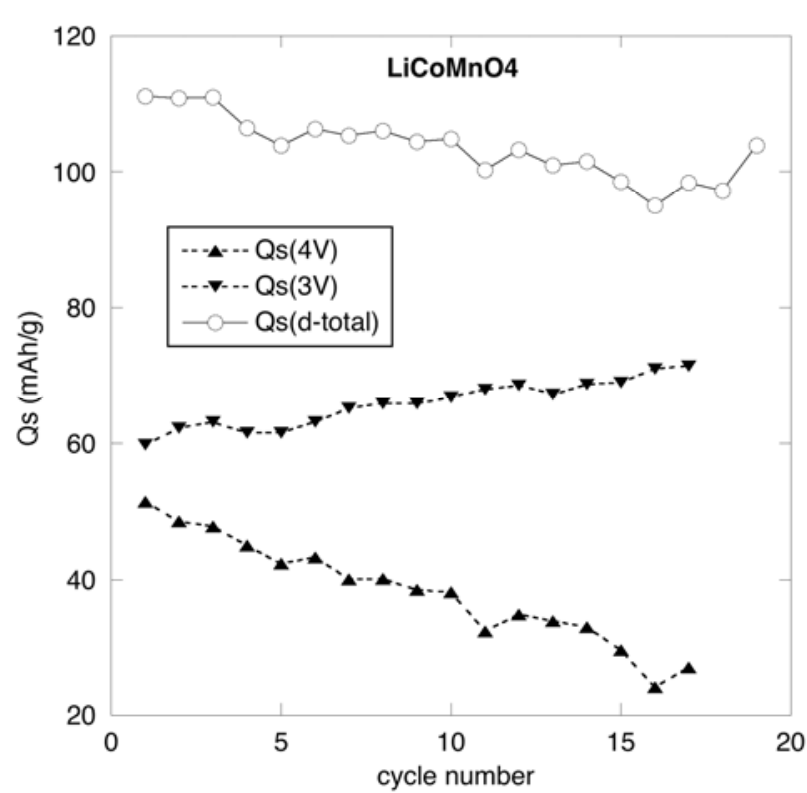

Fig. 7. Evolution of cycling capacity of LCMO with cycling $(\mathrm{C} / 10$, potential window $2.0-4.8 \mathrm{~V})$.

\subsection{Electrochemical behaviour - MCO}

For composition $\mathrm{MnCo}_{0.2} \mathrm{O}_{\approx 2}$ (MCO-20), initial capacities as high as $180 \mathrm{mAh} / \mathrm{g}$ have been found on a single plateau at ca. $2.7 \mathrm{~V}$ [14]. The electrochemical behaviour of other MCO's materials with Co:Mn ratios varying between 0.05 and 0.30 is presented in figures 7 (charge-discharge cycling) and 8 (voltammetric cycling). All compounds in this series exhibit a rather similar behaviour at first glance. Some significant differences can be noted, however : Figure 8 shows that while the initial capacity is comparable for MCO-05, MCO-10 and MCO-20, it is about $15 \%$ lower for MCO-30. On the other hand, MCO-20 shows the flattest plateau (in both discharge and charge), which also shows up as sharper peaks in the voltammogram (Figure 9).

Finally, Figure 9 shows a slight, but systematic shift in the potentials of oxidation and reduction peaks as a function of cobalt content: the peak positions in Figure 9 (for both reduction and oxidation) lie at a higher potential for lower cobalt content. This result may seem surprising, but it should be recalled that XANES measurements showed that cobalt initially enters MCO-20 as $\mathrm{Co}^{2+}$ and is inert from the redox chemistry point of view during the first discharge [15]. The shift in potential probably reflects variations in the manganese energy levels as a result of the perturbation of the $\mathrm{Mn}-\mathrm{O}$ bonding due to the presence of cobalt.

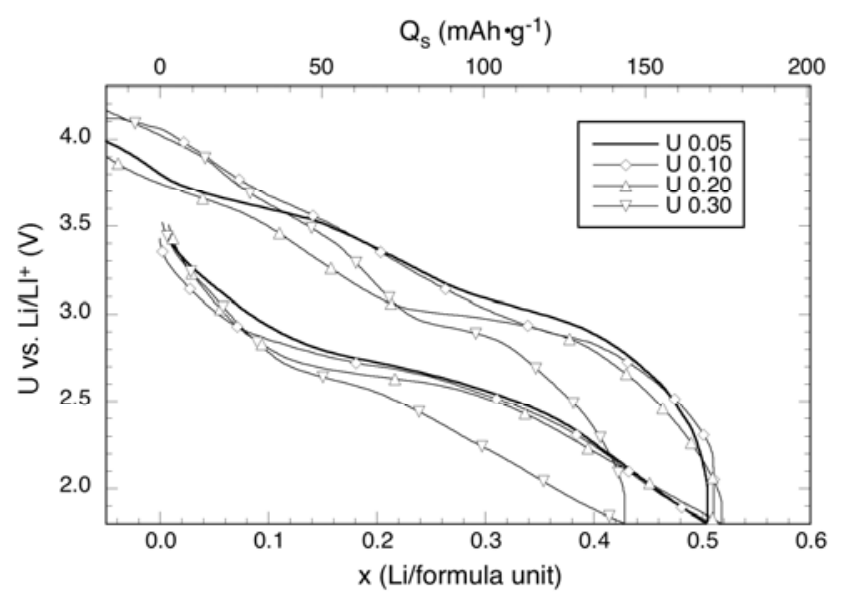

Fig. 8. First charge-discharge cycles at $\mathrm{C} / 20$ of MCO materials for Co:Mn ratios 0.05 to 0.30 .

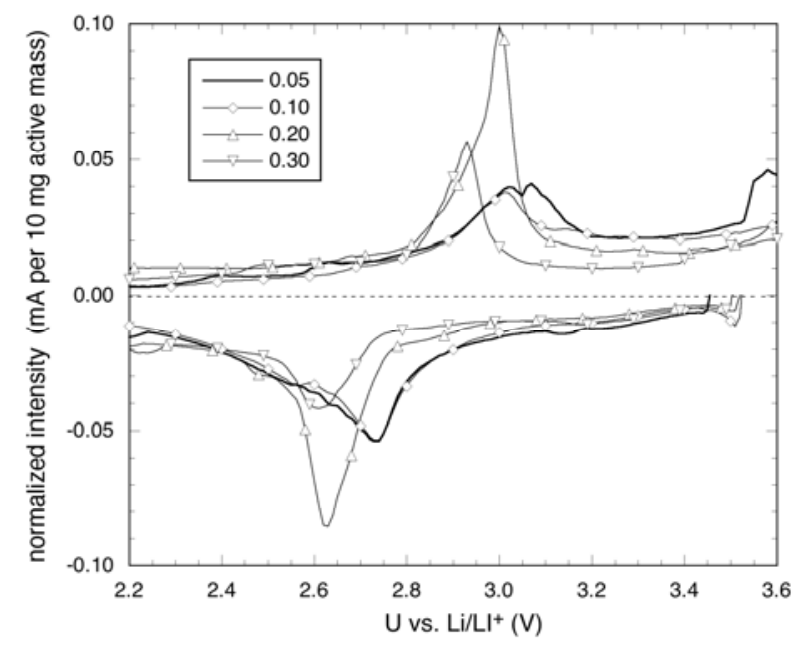

Fig. 9. Slow-scanning voltammograms $(10 \mathrm{mV} / 30 \mathrm{mn}$ steps $)$ of MCO materials for Co:Mn ratios 0.05 to 0.30 . All curves are normalized to $10 \mathrm{mg}$ active material.

Regarding the behaviour on extended cycling, remarkable differences arise as a function of cobalt content. As shown in Figure 10, the capacity decreases quickly on cycling as soon as the Co:Mn ratio departs from 0.20 . This effect is especially severe for Co:Mn $=0.30$ which, unexpectedly, shows very strong capacity fading. The reasons for the existence of an optimum cobalt/manganese ratio are unknown so far, and probably difficult to establish precisely, given the difficulties in gathering accurate structural information about such nanocrystalline materials.

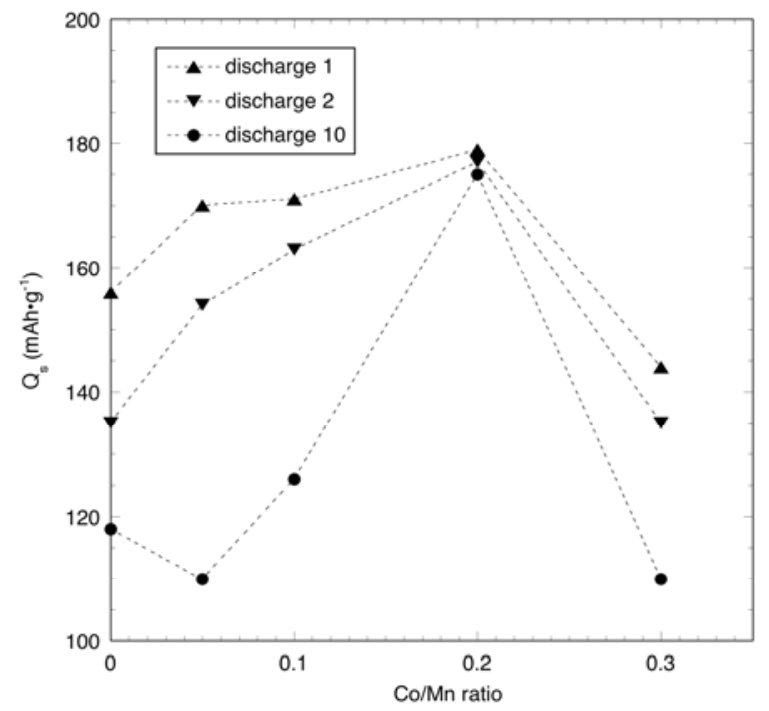

Fig. 10. Comparison of the capacities on 1st, 2nd and 10th discharge as a function of cobalt content $(\mathrm{C} / 20$ regime).

\section{Conclusions}

In this paper, we address the electrochemical performances in lithium batteries of two new manganese-cobalt oxides. The first one, rhombohedral $\mathrm{LiMnCo}_{4}$ ("LMCO"), is a layered oxide with long-range crystalline ordering, where manganese and cobalt behave independently from the oxydo-reduction point of view. A significant capacity is obtained at high potential (ca. $4.4 \mathrm{~V}$ ), but important capacity fade is observed in this voltage region, as in previous studies of Mn-Co oxides with neighbouring structures $[16,20]$. Oddly enough, the $3 \mathrm{~V}$ intercalation reaction, involving the $\mathrm{Mn}^{3+} / \mathrm{Mn}^{4+}$ redox couple, is much more stable on cycling, in spite of the unavoidable Jahn-Teller deformation associated with the presence of the 
$\mathrm{Mn}^{3+}$ oxidation state. The strains induced by the Jahn-Teller effect are probably relaxed by the presence of an important fraction of cobalt in the structure.

The second compound under study (MCO) is odd in several respects. It is nanocrystalline and forms micrometric, perfectly spherical aggregates. Electrochemically, it exhibits a single redox step centered around $2.7 \mathrm{~V}$ on discharge, the position of which is only slightly dependent on cobalt content. Contrary to the LCMO case, no specific plateau attributable to cobalt redox reactions is observed, even for relatively high cobalt content such as Co:Mn $=0.30$.

The most remarkable feature of MCO is the excellent cycling stability of the compound with $\mathrm{Co}: \mathrm{Mn}=0.20$, which could be cycled to 50 cycles with very small capacity fading (see Figure 11). A surprising result is the detrimental effect of higher cobalt substitution levels. Further studies are required to elucidate the exact role of cobalt, and the evolution of the cobalt valence after the first discharge.

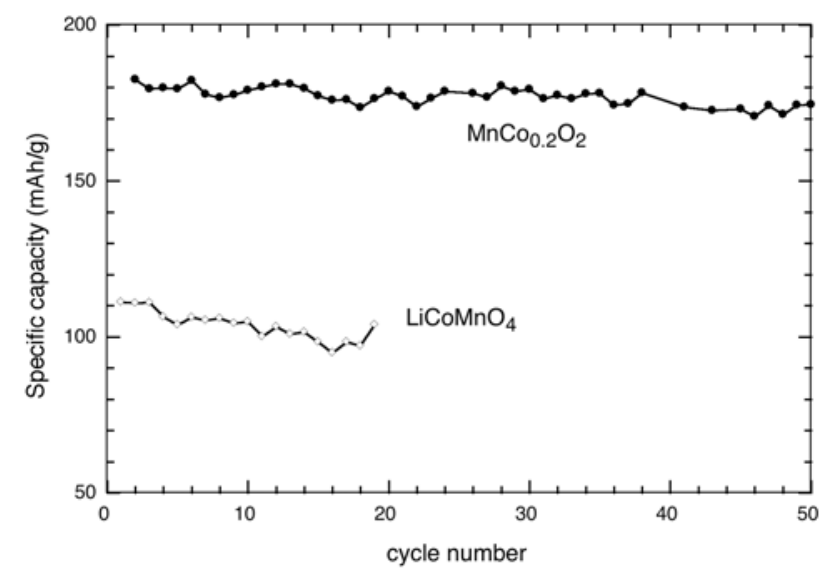

Fig. 11. Comparing the evolution of capacity on cycling for layered $\mathrm{LiCoMnO}_{4}(\mathrm{C} / 10)$ and $\mathrm{X}$-ray amorphous $\mathrm{MnCo}_{0.2} \mathrm{O}_{2}$ $(\mathrm{C} / 20)$. Potential windows as in Figures 6 and 8.

\section{Acknowledgments}

The authors thank C. Darie and S. Pairis for their assistance in SEM measurements.

\section{References}

[1] M.M. Thackeray, Prog. Solid State Chem. 25 (1997) 1.

[2] P.G. Bruce, Phil. Trans. Royal Soc. 354 (1996) 1577

[3] G.H. Li, H. Ikuta H, T. Uchida and M. Wakihara, J.

Electrochem. Soc. 143 (1996) 178.

[4] M. Wohlfahrt-Mehren, A. Butz, R. Oesten, G. Arnold, R.P. Hemmer and R.A. Huggins, J. Power Sources 68 (1997) 582.

[5] F. Bonino, S. Panero, D. Satolli and B. Scrosati, J. Power Sources 97-98 (2001) 389.

[6] Z.L. Liu, A.S. Yu and J.Y. Lee JY, J. Power Sources 74 (1998) 228

[7] C.H. Shen, R.S. Liu, R. Gundakaram, J.M. Chen, S.M. Huang, J.S. Chen and C.M. Wang, J. Power Sources 102 (2001) 21.

[8] S. Franger, S. Bach, J. Farcy, J.P. Pereira Ramos and N. Baffier, J. Power Sources 109 (2002) 262.

[9] M. Tsuda, H. Arai and Y. Sakurai, J. Power Sources 110 (2002) 52.

[10] S.T. Myung, S. Komaba and N. Kumagai, J. Electrochem. Soc. 149 (2002) A1349.

[11] A.R. Armstrong, A.D. Robertson, R. Gitzendanner and

P.G. Bruce, J. Solid State Chem. 145 (1999) 549

[12] M. Jansen and R. Hoppe, Z. anorg. allg. Chem. 408 (1974) 104.

[13] S.W. Li, R. Funahashi, I. Matsubara and S. Sodeoka, Mat. Res. Bull. 35 (2000) 2371.

[14] A. Feltz, W. Ludwig and C. Feibel, Z. anorg. allg. Chem. 540 (1986) 36.

[15] P. Strobel, F. Thiéry, C. Darie, O. Proux, A. Ibarra-Palos, M. Bacia and J.B. Soupart, J. Mater. Chem. 15 (2005) 4799.

[16] A. Kajiyama, K. Takada, T. Inada, M. Kouguchi, S. Kondo and M. Watanabe, J. Electrochem. Soc. 148 (2001) A981.

[17] H. Kawai, M. Nagata, H. Tukamoto and A.R. West, Electrochem. Solid State Lett. 1, 212 (1998).

[18] Y. Koyama, Y. Makimura, I. Tanaka, H. Adachi, T. Ohzuku, J. Electrochem. Soc. 151 (2004) A1499.

[19] P. Strobel et al., to be published.

[20] Z. Bakenov and I. Taniguchi, Solid State Ionics 176 (2005) 1027.

[21] A.R. Armstrong, A.D. Robertson and P.G. Bruce, Electrochim. Acta 45 (1999) 285. 